УДК: 321.7 .3

\title{
THE CHANGE OF POLITICAL REGIME IN KYRGYZSTAN: THE REASONS AND CONSEQUENCES
}

\author{
Sh.A. Aytiev \\ https://orcid.org/0000-0001-8260-2133 \\ Osh State University, Bishkek, Kyrgyz Republic, e-mail: saytiev@yahoo.com
}

\section{DOI:10.14258/ssi(2020)3-05}

This article analyzes the features of political regime as a way of functioning of the society's political system, its role in the post-revolutionary period of formation and development of the Kyrgyz statehood. Many of the pending issues, such as ethno-nationalism, separation of parties on a regional basis, increasing unemployment, inflation, weak, non-developing economy, and security problems of citizens increasing in recent years, as well as the possible political consequences of unresolved problems are specified. The author sets out his own opinion regarding the prospects and ways of the country development in the context of the post-revolutionary situation.

Keywords: state, society, policy, system, regime, process, power, relationships, governance, actor, revolution

\section{ИЗМЕНЕНИЕ ПОЛИТИЧЕСКОГО РЕЖИМА В КЫРГЫЗСТАНЕ: ПРИЧИНЫ И ПОСЛЕДСТВИЯ}

\section{Ш丷. А. Айтиев \\ (iD) https://orcid.org/0000-0001-8260-2133 \\ Ошский государственньй университет, Биикек, Кьргызская Республика, e-mail:saytiev@yahoo.com}

В статье анализируются особенности социально-политического конфликта и его роль в развитии политического режима как способа функционирования политической системы общества в целом. На основе анализа постреволюционного периода становления и развития политической системы обозначено множество нерешенных проблем, в частности этнонационализм, разделенность партий по региональному признаку, нарастающая безработица, инфляция, постоянный рост цен на продукты питания, слабая, практически не развивающаяся экономика, нарастающие за последние годы проблемы безопасности граждан страны, а также возможные последствия нерешенных проблем. При этом в резюмирующем аспекте даны итоги социально-политических конфликтов в Кыргызстане 2015-2010 гг.

Ключевые слова: государство, общество, политика, система, режим, процесс, власть, отночения, правление, революиия 
The tragic events that took place in Kyrgyzstan in April and June 2010 became eloquent proof that the main condition for consistent and effective development of any state, without exception, is the people unity and stability in the society. Never any political problems and differences cannot and should not be resolved through civil society split, clashes between the people and destabilization of the state. In the history the emergence, formation and development of the state occurred on the basis of systematic and consistent settlement of all urgent problems of social, economic and political nature. From the first days of its existence, the activity of the state authority should be focused on the development and implementation of balanced and effective economic policies, literate social policy and a number of other events.

Political regime as a way of functioning of the society political system determining the character of the political life of the society, systematically reflecting the level of political freedom and the attitude of the authorities to the legal framework of their activity.

Clearly, the political regime ensures the stability of political power, which is defined by the controllability of the citizens, dynamics and orientation of political relations acceptable for the authorities. At that it ensures achieving the objectives of both internal and external policies, implementation of policy priorities based on the interests of the state, society as a whole. The process of functioning of the political system itself is determined by the level of development and the intensity of socio-political processes, the status of relationships with the public administration, level of development of socio-political traditions, political consciousness and behavior dominating in the society. The type of legitimacy dominating in the society has a particular importance.

However, before talking about the prospects of political development of the Kyrgyz Republic after the change of political regime in 2010, we should evaluate what achieved our Republic for this period.

As it is known, each revolution generates uncertainty and takes the political system out of a normal condition, in which it functioned until the occurrence of political events, coup for a certain period of time (Ovsyannikov, 2001: 19).

And, as noted by the national historian T.A. Abdrakhmanov: «As the paralysis of power and laws comes, law enforcement and security agencies of the state are demoralized and paralyzed. The State temporarily loses external and domestic immunity. The criminal, inter-ethnic, regional situation aggravates to the bitter end. The country faces the real threat of civil war» (Abdrakhmanov, 2014: 16). Despite the specified moments, our republic achieved certain changes in the political system. So, after the events of 2010 in Kyrgyzstan there were a real competition between politicians, an effective multi-party system was created, decentralization of power and control was implemented. At the present stage of development of Kyrgyzstan, the opposition is no longer on the quasi-legal situation and acts openly within the framework of the law, they have an opportunity to win in the elections within the framework of a political struggle in any region of the republic. Thanks to competition of the parties, it has become possible to ensure openness and transparency of the government. We should also note the growth of freedom of speech, level of independence of the mass media, respect for the rights of people to assemble and meet. Journalists and representatives of civil society today can quite freely criticize govern- 
ment, express their opinions on any matter. Such changes become the basis for the growth of quality characteristics of the entire civil society in the country: self-evaluation is increasing, self-awareness and responsibility of people are growing.

However, as a rule, any large-scale political developments, including the enforced change of power have negative consequences also. These include growing unemployment, inflation, rising prices for food products, weak, and almost stagnating economy; security problems of the country citizens increased in recent years. The absence of effective power hinders the development of the economy, that is confirmed by the indicators of post-revolutionary years, which are not in favor of the new government.

After the revolution, the country governance system has not been radically changed, even in spite of the adoption of the Constitution of 2010, which legally enshrined a parliamentary form of governance.

The new government has not been able to implement declared reforms in the field of decentralization, provision of services to the population, administrative management, law enforcement and judicial systems. Reforms in the system of law enforcement bodies and the judicial power were launched, but virtually failed. Other reforms have not even begun, because the authorities were completely unprepared for them.

Analysis of the situation of the post-revolutionary period in the Kyrgyz Republic has identified a lot of pending and, often, not solvable problems. We should also add to the above the increased ethno-nationalism, which has been spread among both the political elite of the republic and among some part of the Kyrgyz population.

Atmosphere of total intolerance and state-supported public antagonism against objective information about the June events is prevailing. The same attitude is manifested in respect of the activities of human rights defenders, lawyers, journalists and various international institutions that have participated in the protection of the rights of victims (Ismoilov, 2014: 3).

This situation can be recognized as a crisis, and this crisis has been brewing up for more than a year. One more serious symptom of this prolonged crisis in the republic is the fact that citizens preferred to act in resolving their problems not in accordance with the laws of modern state, but according to the concepts of feudal society, they preferred to settle the case on their own rather than appeal to corrupted law enforcement system of the state. A large number of cases, where problems were resolved by illegal methods, became, sadly, a clear evidence of the spread of «lawlessness» in the republic (Shamenov, 2013: 11). Moreover, the trend of ignoring laws and resolving any problems by rallies, demonstrations, blocking strategic roads, leading people on riots, and etc. is widespread in the society, and such things are taking place in our reality, we cannot talk about the ruleof-law state.

At the present stage of development of Kyrgyzstan there is an extreme lack of control in the field of management of political, economic and social processes taking place in the country, and in control in the government machine itself, in its internal controls also. Such negative factors as the separation of parties on a regional basis, pretensions and ambitious claims of those political parties that failed to gain representation in the parliament, presence of former regime public figures among the members of the ruling parties, strength- 
ening and dissemination of religious extremism contribute to further destabilization of the socio-political situation in the Kyrgyz Republic.

The tragic June events in our republic showed that the Uzbek factor cannot, and must not become a destabilizing factor in the region. More likely, here the threat is represented by the regions of the periphery, where the radical moods spread, new non-traditional threats and challenges emerge, which can be provoked due to claims to resources in the center (Ismadiyarov, 2012: 127).

But there is a hope that for the last period, after all the trials faced by the citizens of Kyrgyzstan, the society formed the need for alternative lifestyle (without armed conflicts, without the permanent threats and riots), and new social strata aimed at the building of a peaceful and prosperous society.

What are the prospects for the development of Kyrgyzstan in this case?

We should be aware that the threat of unrests in the Republic has not been yet removed, that there are many problems to be resolved. And these factors determine the prospects of development of Kyrgyzstan.

If the leaders of the republic, including the Zhogorku Kenesh and the President, does not resolve the problems described previously, it's likely that a new wave of unrest and violence in the country can rise, which will be provoked by both disaffected politicians and part of the population dissatisfied with the situation. Historically, the stability in the society, its prosperity depended on political leaders (present and future), on how they realized the fact that every short-sighted and politically immature act, non-conscious political responsibility can destabilize the country, bring it to the next conflict situation, which will manifest itself in riots, ethnic feuds, and destabilization in all spheres of society.

To avoid such risks, we should very competently and professionally manage the state government structures.

The President should pursue very correct and diplomatic policies, make political compromises, and build relationships with his political rivals through dialogue and agreements, as well as make compromises that can preserve a majority coalition in the parliament (Bolponova, 2015). He must learn to use the mechanism of manipulation of individual politicians, taking into account the actual and potential leaders, as well as very authoritative «shadow» figures, the so-called «gray cardinals»...

Another important factor in improving the political situation in the country and enhancing the state governance can be a high degree of awareness of the political leaders of their historical responsibility for the future of the country. This means, first and foremost, the possession of competent technologies of political leader, which is reflected in the culture, etiquette, ability to serve as an example of lawfulness, civic responsibility, respect for the laws and orders, respecting the requirements to morality standards commonly accepted in the society, steadfast and consistent protection of national and state interests.

Some political analysts see the only real prospect for changing the situation in the country in the formation of a new - much stronger and actually democratic - opposition movement of civil forces (Shamenov, 2013: 34). Such a movement should cope with a task of establishing political monitoring of the actions of the authorities; have universal support of the population, which will ensure the successful political struggle at the next election to 
the Zhogorku Kenesh, in order to achieve the actually legitimate, representative parliamentary majority. Thus, there will take place a legitimate change of not just power but change of the today's extremely inefficient political establishment, or, at least, its unjustified monopoly on power will be destroyed. In case of success, a new generation of politicians must restore fairness and efficiency of the state power, redirect its resources towards implementation of real reforms, radical improvement of the situation in the republic and adoption of decisive measures for comprehensive modernization of the republic. But it should be noted that regardless of political events, the main state mechanisms of government with appropriate political institutions formed in the country. Kyrgyzstan is a recognized actor in international relations, having a legitimate right to response to challenges and threats of the modern world.

\section{БИБЛИОГРАФИЧЕСКИЙ СПИСОК}

Абдрахманов Т.А. О революционном синдроме. В кн.: Роль и историческое значение Апрельской революции в современной истории Кыргызстана: сборник материалов внутриуниверситетской научно-практической конференции. Бишкек: Кыргызский государственный университет им. И.Арабаева, 2014. С. 124-127.

Болпонова А. Апрельские события 2010 года в Кыргызстане, 12 октября 2015.. URL: http://kk.convdocs.org/docs/

Исмоилов С. Июньские события 2010 года в Кыргызстане: последствия и отголоски, 15 марта 2014. URL: http://unhcr.org.ua/img/uploads

Исмадияров У. Проблемы и перспективы развития политической системы стран Центральной Азии. Москва, 2012.

Овсянников Н. Трагедии и истории государств Юго-Восточной Азии. Москва, 2001.

Шаменов Н. Безопасность и ее формы в условиях революции. Алматы, 2013.

\section{REFERENCES}

Abdrakhmanov, T.A. (2014). O revolucionnom sindrome [About the revolutionary syndrome]. In: Rol' $i$ istoricheskoe znachenie Aprel'skoj revolyucii v sovremennoj istorii Kyrgyzstana: sbornik materialov vnutriuniversitetskoj nauchno-prakticheskoj konferencii., [The role and the historical significance of the April revolution in the modern history of Kyrgyzstan: proceedings of the Interuniversity scientific and practical conference]. Bishkek: Arabaev Kyrgyz State University.

Bolponova, A. (2015). Aprelskiye sobytiya $2010 \mathrm{v}$ Kyrgyzstane [April events of $2010 \mathrm{in} \mathrm{Kyr-}$ gyzstan]. URL: http://kk.convdocs.org/docs/

Ismoilov, S. (2014). Iyunskiye sobytiya 2010 goda v Kyrgyzstane: posledstviya i otgoloski [The June events of 2010 in Kyrgyzstan: consequences and repercussions], 15 March 2014. URL: http://unhcr.org.ua/img/uploads

Ismadiyarov, U. (2012). Problemy i perspektivy razvitiya politicheskoj sistemy stran Centralnoj Azii [Problems and prospects of development of political system of Central Asian countries]. Moscow. 
Ovsyannikov, N. (2001). Tragedii v istorii gosudarstv Yugo-Vostochnoj Azii [Tragedies in the history of South Asian states]. Moscow.

Shamenov, N. (2013). Bezopasnost' i ee formy v usloviyah revolyucii [Safety and it's forms in the terms of revolution]. Almaty. 